Przegląd Badań Edukacyjnych Educational Studies Review

ISSN 1895-4308

nr 19 (2/2014), s. 7-24

Nina Ogińska-Bulik

Uniwersytet Łódzki, e-mail: noginska@uni.lodz.pl

Magdalena Zadworna-Cieślak

Społeczna Akademia Naukw Łodzi, e-mail: magzad@wp.pl
ORYGINALNE

ARTYKUtY

BADAWCZE

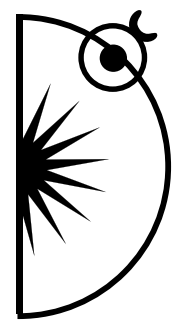

\title{
Rola prężności psychicznej w radzeniu sobie ze stresem związanym z egzaminem maturalnym
}

DOI: http://dx.doi.org/10.12775/PBE.2014.019

\section{The Role of Resiliency in Coping with Stress Related to the Matriculation Examination}

\begin{abstract}
The aim of this study was to determine the role of resiliency in coping with stress related to the matriculation examination. Additionally, it was analysed whether the strategies used change as the examination approaches. The study involved 82 secondary school students of the final year at the age of 18-19. The Resiliency Assessment Scale - SPP-25 and the Multidimensional Inventory for Measuring Stress Coping - COPE were applied. The COPE study focused on assessing the strategies used in coping with stress related to the matriculation exam (situational version). It was conducted twice, the second one took place 3 months after the first one (two weeks before the exam). It occurred that resiliency was significantly associated with the strategies of coping with stress in both stages of the study, however it was stronger in the period immediately preceding the final examination. The correlation between resiliency and adaptive strategies, such as active coping with stress and positive reframing were positive, while the correlation between avoidance strategies, such as denial or behavioural disengagement were negative. The study shows that resiliency may significantly increase the effectiveness of coping with examination stress.
\end{abstract}

Key words: resiliency, coping with stress, stress examination. 


\section{Wprowadzenie}

Zdawanie egzaminów, pisanie sprawdzianów czy klasówek jest dla dzieci i młodzieży poważnym źródłem stresu. Ze szczególnie wysokim jego poziomem wiąże się zdawanie egzaminu dojrzałości, który jest równocześnie przepustką na wyższą uczelnię. Tymczasem współczesne teorie stresu większe znaczenie przypisują podejmowanej przez jednostkę aktywności zaradczej, w postaci różnych strategii radzenia sobie, niż działaniu samych stresorów. Wybór strategii radzenia sobie ze stresem zależy wprawdzie od rodzaju doświadczanej sytuacji i jej oceny, ale przede wszystkim od właściwości podmiotowych jednostki.

W literaturze wskazuje się na dużą różnorodność wykorzystywanych przez młodzież strategii radzenia sobie ze stresem (Compas, Connor-Smith, Saltzman, Harding Thomsen, Wadsworth, 2001; Pisula, 2003). Proces radzenia sobie ze stresem egzaminacyjnym jest rozciagnięty w czasie i obejmuje fazy: przygotowawcza, konfrontacji, oczekiwania na wyniki i wyników (Zeidner, 1995). Najważniejsza jest faza przygotowania (antycypacyjna), w której jednostka podejmuje działania mające na celu poradzenie sobie z występującym obciążeniem. Faza ta poprzedza sam egzamin i rozpoczyna się w momencie, kiedy uczeń zdaje sobie sprawę ze zbliżającego się egzaminu i obciążeń z nim związanych. Jednocześnie w fazie tej uruchamiane są emocje, zarówno te pozytywne - związane z myślami o sukcesie, jak i negatywne - wiążące się z obawami przed porażką. Faza przygotowania do egzaminu jest sytuacją kontrolowalną, a jej efekty zależą przede wszystkim od samego ucznia. Dlatego też za najbardziej adaptacyjne $\mathrm{w}$ tej fazie uważane są działania zorientowane na problem, choć podejmowane są także strategie skoncentrowane na emocjach, które pozwalają uczniowi zmniejszyć napięcie i lęk przed zbliżającym się egzaminem. Prowadzone w tym zakresie badania potwierdziły, że najczęściej wykorzystywane przez nastolatków są strategie skoncentrowane na problemie (Gibson, i in., 1991), zmniejsza się natomiast korzystanie ze strategii unikowych (Gelhaar, i in., 2007). Podkreśla się także, że młodzież w procesie radzenia sobie ze stresem egzaminacyjnym korzysta z kilku strategii jednocześnie (Zeidner, 1995).

Wśród właściwości osobowości, które wpływają na dobór strategii radzenia sobie, wymienia się stabilność emocjonalna, poczucie koherencji, własnej wartości, skuteczności, optymizm życiowy (Heszen-Niejodek, 2002, Ogińska-Bulik, 2012, Ogińska-Bulik, Juczyński, 2010). Można przypuszczać, że w procesie skutecznego radzenia sobie ze stresem egzaminacyjnym istotną rolę będzie odgrywać prężność psychiczna, traktowana jako podmiotowa właściwość jednostki. 
Termin „prężność” ${ }^{1}$ jest tłumaczeniem słowa resilience, które pochodzi od łacińskiego salire, oznaczającego sprężynować (ang. spring, spring up) i resilire, oznaczające odbijać się, powracać do poprzedniego stanu (ang. springback). Literatura posługuje się dwoma terminami: resilience i resiliency. To pierwsze jest utożsamiane $\mathrm{z}$ procesem skutecznego przezwyciężania negatywnych zjawisk i wydarzeń życiowych. Drugie oznacza właściwość osobowości czy względnie trwały zasób jednostki i określane jest jako prężność psychiczna².

Prężnośćrozumianaw pierwszym znaczeniu (jako proces) odnosi się do procesu dynamicznej, pozytywnej adaptacji w obliczu pojawiających się przeciwności. Aktywowanie resilience wymaga doświadczenia bezpośredniego zagrożenia lub sytuacji o charakterze traumatycznym oraz utrzymania możliwości i kompetencji pozwalających na poradzenie sobie z nimi (Luthar i in. 2000). Częściej jednak prężność rozumiana jest jako właściwość osobowości. Jeanne i Jack Block (Block, Block, 1980; Block, Kremen, 1996) traktują prężność jako względnie trwałą dyspozycję, determinującą proces elastycznej adaptacji do ciaggle zmieniających się wymagań życiowych. Ujmują ją więc jako cechę osobowościową (ego-resiliency) istotną w procesie zmagania się, zarówno z wydarzeniami o charakterze traumatycznym, jak i zdarzeniami występujących w życiu codziennym. Wśród polskich badaczy takie rozumienie prezentują Zenon Uchnast (1997) oraz Piotr Oleś (2000), stosując określenie prężność-ego. Rozumienie prężności jako podmiotowej właściwości człowieka prezentuje także Barbara Fredrickson (2001), traktując ją jako trwały zasób jednostki, który najczęściej pojawia się w wyniku doświadczania przez osobę poważnych trudności lub zagrożenia.

Nina Ogińska-Bulik i Zygfryd Juczyński (2008) traktują prężność jako mechanizm samoregulacji, obejmujący zarówno elementy poznawcze, charakterystyczne dla przekonań i oczekiwań, a dotyczące m.in. spostrzegania rzeczywistości w kategoriach wyzwania, a także własnych kompetencji, jak i emocjonalne, obejmujące afekt pozytywny i stabilność emocjonalną oraz behawioralne, wyrażające się w poszukiwaniu nowych doświadczeń i podejmowaniu różnorodnych i skutecznych strategii radzenia sobie z problemami. Zgodnie z ujęciem Blocka (Block, Kremen, 1996) prężność stoi w opozycji zarówno do braku kontroli (impulsywność), jak jej nadmiaru (sztywność).

${ }^{1}$ W polskiej literaturze stosowane są także terminy: „sprężystość” oraz „rezyliencja”.

${ }^{2}$ Konstrukt prężności został szerzej omówiony w książce Osobowość, stres a zdrowie oraz artykułach autorstwa N. Ogińskiej-Bulik i Z. Juczyńskiego,Skala pomiaru prężności - SPP-25 oraz Prężność u dzieci i młodzieży: charakterystyka i pomiar-polska skala SPP-18. 
Prężność psychiczna sprzyja wytrwałości i elastycznemu przystosowaniu się do wymagań życiowych, ułatwia mobilizację do podejmowania działań zaradczych w trudnych sytuacjach, a także zwiększa tolerancję negatywnych emocji i niepowodzeń. Osoba odznaczająca się wysokim poziomem prężności jest pozytywniej nastawiona do życia. Jednostka prężna charakteryzuje się stabilnością emocjonalną, napotkane trudności postrzega częściej jako szansę na zdobycie nowych doświadczeń, a siebie skłonna jest uważać za osobę mająca wpływ na podejmowanie decyzji (Ogińska-Bulik, Juczyński, 2008, 2010, 2011; Semmer, 2006). Wiele badań wykazało znaczenie prężności dla funkcjonowania osób dorosłych, m.in. jako czynnika chroniącego przed negatywnymi skutkami doświadczanego stresu zawodowego (Ogińska-Bulik, 2011a), sprzyjającego przystosowaniu się do choroby (Ogińska-Bulik, 2011b), występowaniu pozytywnych zmian po traumie (Felcyn-Koczewska, Ogińska-Bulik, 2011) czy obniżającego ryzyko uzależnienia od jedzenia (Chanduszko-Salska, Ogińska-Bulik, 2011).

Prężność wydaje się także pełnić istotną rolę w funkcjonowaniu dzieci i młodzieży. Dzieci charakteryzujące się wysokim poziomem prężności ujawniają wyższe poczucie sensowności podejmowanych działań, pozytywne nastawienie do życia, wyższy poziom autonomii i zaufania do siebie, a także wyższą sprawność w działaniach niezbędnych w codziennym funkcjonowaniu. Ponadto wykazują większą wnikliwość oraz wyższe umiejętności interpersonalne, ułatwiające nawiązywanie ciepłych i serdecznych relacji z innymi dzieci (Chuang, Lamb, Hwang, 2006; Klohnen, 1996).

Uczniowie z wyższym wskaźnikiem prężności są bardziej pilni, uważni, zdolni do koncentracji, pomocni i skłonni do współpracy (Hart i wsp., za: Torgersen, Vollrath, 2006). Dostarczono także danych świadczących, że dzieci o wyższym nasileniu prężności, w porównaniu z dziećmi o niskim nasileniu tej cechy, charakteryzują się wyższym poziomem inteligencji oraz niższymi wskaźnikami objawów psychopatologii (Robins, i in., 1996).

Wysoki poziom prężności okazał się czynnikiem pełniącym funkcję chroniącą nastolatków przed podejmowaniem zachowań ryzykownych i szkodliwych dla zdrowia (Ogińska-Bulik, 2010). W badaniach japońskich wykazano, że prężność u adolescentów wiąże się pozytywnie z poczuciem własnej wartości (Oshio, i in., 2002) oraz lepszym stanem zdrowia psychicznego (Oshio, i in., 2003).

Jednostki odznaczające się prężnością skuteczniej radzą sobie ze stresem. Skuteczność ta wiąże się m.in. z częstszym wykorzystywaniem w procesie radzenia strategii powiązanych z emocjami pozytywnymi, takich jak koncentra- 
cja na zadaniu, pozytywne przewartościowanie czy nadawanie pozytywnego znaczenia zwykłym wydarzeniom. Z kolei doświadczanie emocji pozytywnych wpływa dodatnio na procesy poznawcze, tj. poszerza zakres uwagi, zwiększa zdolność do elastycznego i kreatywnego myślenia, ale także powiększa zasoby radzenia sobie (Fredrickson, 2001). Pozwala to na bardziej skuteczne radzenie sobie, obecnie i w przyszłości. Można więc zakładać, że prężność będzie odgrywać istotną rolę w doborze strategii radzenia sobie w sytuacji stresu związanego $\mathrm{z}$ egzaminem maturalnym. Zagadnienie to, jak dotąd, nie było przedmiotem badań.

\section{Cel i metoda badań}

Podstawowym celem podjętych badań była ocena zależności między prężnością psychiczną a wyborem strategii radzenia sobie ze stresem maturalnym. Ponadto zbadano również, czy w miarę zbliżania się terminu egzaminu maturalnego dochodzi do zmiany strategii radzenia sobie ze stresem.

W pierwszym etapie badania, który odbył się 3 miesiące przed matura, uczestniczyło 82 uczniów ostatniej klasy liceum ogólnokształcącego, w wieku 18-19 lat. Badania przeprowadzono w jednym z miast centralnej Polski. Większość badanych stanowiły dziewczęta (65\%). Do etapu drugiego, 2 tygodnie przed maturą, przystąpiło 69 osób, tj. 85\% badanych, w tym 25 chłopców i 44 dziewczęta. W badaniach zastosowano Skalę Pomiaru Prężności - SPP25 oraz Wielowymiarowy Inwentarz do Pomiaru Radzenia Sobie ze Stresem - COPE.

Skala Pomiaru Prężności - SPP-25, której autorami są Nina Ogińska-Bulik i Zygfryd Juczyński (2008), pozwala na pomiar ogólnego poziomu prężności, traktowanej jako właściwość osobowości oraz pięciu czynników wchodzących w jej skład, którymi są: 1) wytrwałość i determinacja w działaniu, 2) otwartość na nowe doświadczenia i poczucie humoru, 3) kompetencje osobiste i tolerancja negatywnych emocji, 4) tolerancja na niepowodzenia i traktowanie życia jako wyzwania oraz 5) optymistyczne nastawienie do życia i zdolność mobilizowania się w trudnych sytuacjach. Oceny tych właściwości dokonuje się na 5-stopniowej skali typu Likerta (od $0-z$ decydowanie nie do $4-z$ decydowanie tak). Ogólny wynik SPP-25 stanowi sumę pięciu wyróżnionych czynników. Im wyższy wynik, tym wyższe nasilenie prężności. Wynik ogólny SPP-25 można wyrazić w skali stenowej, w której wyniki w zakresie 1-4 oznaczają niską prężność, 5-6 - średnią, a 7-10 - wysoką. Skala uzyskała satysfakcjonujące właściwości psychometryczne (rzetelność mierzona współczynnikiem alfa 
Cronbacha wynosi 0,89 ; stabilność bezwzględna, mierzona metodą testu-retestu po 4 tyg. wynosi 0,85$)$.

Wielowymiarowy Inwentarz do Pomiaru Radzenia Sobie ze Stresem COPE, którego autorami są Charles S. Carver, Michael F. Scheier, Jagdish K. Weintraub został zaadaptowany do warunków polskich przez Z. Juczyńskiego i N. Ogińską-Bulik (2009). Inwentarz zawiera 60 stwierdzeń i służy do oceny 15 sposobów radzenia sobie ze stresem. Osoba badana ocenia każdą z podanych pozycji, posługując się skalą 4-stopniową: od 1 - nigdy tak nie postęuję do 4 - zawsze tak postępuję. Każdą ze strategii ocenia się oddzielnie, dodając do siebie punkty z poszczególnych stwierdzeń wchodzących $\mathrm{w}$ ich skład (po 4 dla każdej strategii). Inwentarz pozwala na wyróżnienie strategii skoncentrowanych na problemie, strategii zaliczanych do zachowań unikowych oraz związanych z poszukiwaniem wsparcia społecznego i koncentracją na emocjach. W badaniach wykorzystano wersję narzędzia, która odnosi się do oceny strategii radzenia sobie dotyczących konkretnej sytuacji, którą był egzamin maturalny (wersja sytuacyjna). Badania przeprowadzono dwukrotnie, pierwszy raz na 3 miesiące przed egzaminem maturalnym, drugi raz 2 tygodnie przed maturą ( 3 miesiące po pierwszym badaniu).

\section{Wyniki badań}

Analizę wyników badań przeprowadzono za pomocą pakietu statystycznego Statistica (wersja 8.0). Wykorzystując test Kołmogorowa-Smirnowa, sprawdzono normalność rozkładów dla zmiennych włączonych do analizy, tj. prężności i preferowanych strategii radzenia sobie ze stresem. Obliczono wartości średnie uwzględnionych w badaniu zmiennych, tj. poziomu prężności (tab. 1) oraz preferowanych strategii radzenia sobie ze stresem w obydwu etapach badania (tab. 2). Następnie ustalono zależności między badanymi zmiennymi (tab. 3-8).

Płeć nie różnicuje ogólnego wyniku prężności. Jedynie czynnik 3, wchodzący w skład prężności, związany był z płcią badanych, tj. chłopcy wykazywali statystycznie istotnie wyższy poziom kompetencji osobistych do radzenia sobie i tolerancji negatywnych emocji $(\mathrm{M}=14,36 ; \mathrm{SD}=2,21)$ niż dziewczęta $(\mathrm{M}=12,89, \mathrm{SD}=3,21 ; \mathrm{t}=2,43 ; \mathrm{p}<0,02)$. Zaznaczyły się jednak pewne różnice $\mathrm{w}$ odniesieniu do strategii radzenia sobie (analizowanych w pierwszym etapie badań). Chłopcy uzyskali wyższe średnie wyniki niż dziewczęta w zakresie: Unikania konkurencyjnych działań (Cope 5), Powstrzymywania się od działania (Cope 8), Zaprzeczania (Cope 11), Zażywania alkoholu lub Innych środków psychoaktywnych (Cope 14) oraz Poczucia humoru (Cope 15). Z kolei dziew- 
Nina Ogińska-Bulik, Magdalena Zadworna-Cieślak Rola prężności psychicznej w radzeniu...

częta przewyższały chłopców w zakresie strategii takich jak: Poszukiwanie wsparcia emocjonalnego (Cope 4), Koncentracja na emocjach i ich wyładowanie (Cope 10) oraz Odwracanie uwagi (Cope 12). Pomimo występujących różnic $\mathrm{w}$ zakresie strategii radzenia sobie, nie uwzględniono płci w dalszych analizach, przede wszystkim ze względu na zbyt małą liczbę osób badanych.

Obliczono także średnie i odchylenia standardowe w zakresie prężności i jej poszczególnych wymiarów (tab. 1). Średnie wartości prężności w badanej grupie nastolatków są zbliżone do wyników uzyskanych w badaniach normalizacyjnych (Ogińska-Bulik, Juczyński, 2008) i odpowiadają wartości 5. stena.

Tabela 1. Średnie i odchylenia standardowe w zakresie prężności i jej wymiarów

\begin{tabular}{|l|c|c|c|c|}
\hline \multicolumn{1}{|c|}{ Zmienne } & M & SD & Min & Max \\
\hline Prężność - wynik ogólny & 68,97 & 10,68 & 27 & 90 \\
\hline Wytrwałość i determinacja w działaniu & 13,74 & 2,71 & 6 & 19 \\
\hline Otwartość na nowe doświadczenia i poczucie humoru & 15,34 & 2,54 & 4 & 20 \\
\hline Kompetencje osobiste i tolerancja negatywnych emocji & 13,41 & 2,98 & 3 & 19 \\
\hline Tolerancja na niepowodzenia i traktowanie życia jako wyzwania & 14,23 & 2,52 & 6 & 19 \\
\hline $\begin{array}{l}\text { Optymistyczne nastawienie do życia i zdolność mobilizowania się } \\
\text { w trudnych sytuacjach }\end{array}$ & 12,25 & 2,85 & 4 & 19 \\
\hline
\end{tabular}

W tabeli 2 porównano średnie wybieranych przez młodzież strategii radzenia sobie ze stresem egzaminacyjnym w pierwszym i drugim etapie badań. Istotność różnic ustalono, wykorzystując test dla prób zależnych.

Średnie nasilenie poszczególnych strategii radzenia sobie ze stresem u badanej młodzieży nie odbiega znacząco od wyników amerykańskich, uzyskanych za pomocą inwentarza COPE w wersji sytuacyjnej (Carver i in., za: Juczyński, Ogińska-Bulik, 2009).

Tabela 2. Zróżnicowanie strategii radzenia sobie w obydwu etapach badań

\begin{tabular}{|c|c|c|c|c|c|c|}
\hline \multirow[t]{2}{*}{ ZMIENNE } & \multicolumn{2}{|c|}{$\begin{array}{c}\text { ETAP I } \\
\text { (3 miesiące przed } \\
\text { maturą) }\end{array}$} & \multicolumn{2}{|c|}{$\begin{array}{c}\text { ETAP II } \\
\text { (2 tygodnie przed } \\
\text { maturą) }\end{array}$} & \multirow[t]{2}{*}{ Test $\mathrm{t}$} & \multirow[t]{2}{*}{$\begin{array}{l}\text { Poziom } \\
\text { istotno- } \\
\text { ści p }\end{array}$} \\
\hline & M & SD & M & SD & & \\
\hline COPE 1 - Aktywne radzenie sobie & 11,18 & 1,47 & 11,08 & 1,96 & .44 & $\mathrm{Ni}$ \\
\hline COPE 2 - Planowanie & 10,34 & 2,51 & 11,18 & 2,51 & $-3,48$ & .001 \\
\hline $\begin{array}{l}\text { COPE } 3 \text { - Poszukiwanie wsparcia instrumen- } \\
\text { talnego }\end{array}$ & 11,07 & 2,92 & 11,31 & 2,21 & -.82 & $\mathrm{Ni}$ \\
\hline
\end{tabular}


Tabela 2. Cd.

\begin{tabular}{|l|c|c|c|c|c|c|}
\hline $\begin{array}{l}\text { COPE } 4 \text { - Poszukiwanie wsparcia } \\
\text { emocjonalnego }\end{array}$ & 11,57 & 2,90 & 10,81 & 2,42 & 2,82 & .01 \\
\hline COPE 5 - Unikanie konkurencyjnych działań & 9,89 & 2,01 & 10,17 & 2,23 & $-1,06$ & $\mathrm{Ni}$ \\
\hline COPE 6 - Zwrot ku religii & 8,02 & 4,08 & 7,71 & 3,68 & 1,29 & $\mathrm{Ni}$ \\
\hline $\begin{array}{l}\text { COPE 7 - Pozytywne przewartościowanie } \\
\text { i rozwój }\end{array}$ & 10,63 & 2,29 & 11,20 & 2,01 & $-1,92$ & $\mathrm{Ni}$ \\
\hline COPE 8 - Powstrzymywanie się od działania & 10,02 & 2,13 & 9,75 & 7,71 & .96 & $\mathrm{Ni}$ \\
\hline COPE 9 - Akceptacja & 10,00 & 2,46 & 9,21 & 2,28 & 2,92 & .05 \\
\hline $\begin{array}{l}\text { COPE 10 - Koncentracja na emocjach i ich } \\
\text { wyładowanie }\end{array}$ & 11,27 & 2,79 & 10,95 & 2,62 & 1,21 & $\mathrm{Ni}$ \\
\hline COPE 11 - Zaprzeczanie & 6,63 & 1,87 & 6,56 & 2,17 & .28 & $\mathrm{Ni}$ \\
\hline COPE 12 - Odwracanie uwagi & 8,97 & 2,19 & 8,81 & 2,32 & 1,96 & $\mathrm{Ni}$ \\
\hline COPE 13 - Zaprzestanie działań & 6,75 & 2,23 & 6,56 & 2,01 & 1,01 & $\mathrm{Ni}$ \\
\hline $\begin{array}{l}\text { COPE 14 - Zażywanie alkoholu lub Innych } \\
\text { środków psychoaktywnych }\end{array}$ & 6,56 & 3,51 & 6,22 & 3,06 & 1,05 & $\mathrm{Ni}$ \\
\hline COPE 15 - Poczucie humoru & 6.62 & 2,61 & 6,81 & 2,53 & -.60 & $\mathrm{Ni}$ \\
\hline
\end{tabular}

Najczęściej wykorzystywanymi strategiami na 3 miesiące przed maturą było poszukiwanie wsparcia emocjonalnego i instrumentalnego, koncentracja na emocjach i ich wyładowanie oraz aktywne radzenie sobie. Najrzadziej zaś występowało zażywanie alkoholu i innych substancji psychoaktywnych, poczucie humoru i zaprzeczanie.

$\mathrm{Na}$ dwa tygodnie przed maturą badana młodzież korzystała przede wszystkim z poszukiwania wsparcia instrumentalnego, pozytywnego przewartościowania oraz planowania działań. Najrzadziej stosowanymi strategiami było zażywanie alkoholu i innych substancji psychoaktywnych, zaprzeczanie i zaprzestanie działań. Jak wynika $\mathrm{z}$ danych zawartych $\mathrm{w}$ tabeli 2 , u badanych maturzystów w miarę zbliżania się egzaminu wzrosła częstotliwość korzystania ze strategii planowania, zmniejszyła się natomiast skłonność do poszukiwania wsparcia emocjonalnego i akceptacji. Uzyskane wskaźniki wielkości efektu (d-Cohena dla strategii 2 - planowanie $=-0,63$, dla strategii 4 - poszukiwanie wsparcia emocjonalnego $=0,50$, dla strategii $9-$ akceptacja $=0,50)$ dla testu $\mathrm{t}$ dla prób zależnych okazały się umiarkowane, co nakazuje ostrożne formułowanie wniosku o istnieniu różnic między średnimi.

W kolejnym etapie analiz, wykorzystując współczynniki korelacji Pearsona, ustalono związek pomiędzy prężnością i jej wymiarami a strategiami radze- 
Nina Ogińska-Bulik, Magdalena Zadworna-Cieślak Rola prężności psychicznej w radzeniu...

nia sobie ze stresem w obu etapach badania. Współczynniki korelacji istotne statystycznie przedstawia tabela 3.

Tabela 3. Współczynniki korelacji pomiędzy ogólnym poziomem prężności a strategiami radzenia sobie ze stresem

\begin{tabular}{|c|c|}
\hline \multicolumn{2}{|c|}{ PRĘŻNOŚĆ - WYNIK OGÓLNY } \\
\hline ETAP I & ETAP II \\
\hline $\begin{array}{l}\text { COPE } 1 \text { - Aktywne radzenie sobie } \\
r=.35^{* *}\end{array}$ & $\begin{array}{l}\text { COPE 1: Aktywne radzenie sobie } \\
\mathrm{r}=.36^{* *}\end{array}$ \\
\hline $\begin{array}{l}\text { COPE } 7 \text { - Pozytywne przewartościowanie i rozwój } \\
r=.40^{\star \star \star}\end{array}$ & $\begin{array}{l}\text { COPE 7: Pozytywne przewartościowanie i rozwój } \\
\mathrm{r}=.44^{\star \star \star}\end{array}$ \\
\hline $\begin{array}{l}\text { COPE } 13 \text { - Zaprzestanie działań } \\
r=-.36^{* *}\end{array}$ & $\begin{array}{l}\text { COPE 13: Zaprzestanie działań } \\
\mathrm{r}=-.56^{\star \star *}\end{array}$ \\
\hline $\begin{array}{l}\text { COPE } 10 \text { - Koncentracja na emocjach i ich } \\
\text { wyładowanie } \\
\mathrm{r}=-.26^{\star \star}\end{array}$ & $\begin{array}{l}\text { COPE 11: Zaprzeczanie } \\
r=-.42^{* * *}\end{array}$ \\
\hline $\begin{array}{l}\text { COPE } 5 \text { - Unikanie konkurencyjnych działań } \\
\mathrm{r}=.20^{*}\end{array}$ & \\
\hline
\end{tabular}

${ }^{*} p<.05 ;{ }^{* *} p<.01 ;{ }^{* * *} p<.001$

Zarówno w pierwszym, jak i w drugim etapie badań wykazano dodatni związek aktywnego radzenia sobie i pozytywnego przewartościowania z ogólnym poziomem prężności, z kolei zależność ujemna dotyczyła zaprzestania działań. Związki te okazały się silniejsze na 2 tygodnie przed maturą. Ponadto na 3 miesiące przed maturą (etap 1) z poziomem prężności powiązane były także takie strategie jak: unikanie konkurencyjnych działań (dodatnio) oraz koncentracja na emocjach i ich wyładowanie (ujemnie), których to związków nie zanotowano przed samym egzaminem maturalnym. W sytuacji zbliżającej się matury (etap 2) zaznaczył się także ujemny związek prężności z zaprzeczaniem.

Dodatkowo sprawdzono, które z wymiarów prężności powiązane są $\mathrm{w}$ największym stopniu $\mathrm{z}$ wybieranymi przez młodzież strategiami radzenia sobie ze stresem związanym $\mathrm{z}$ egzaminem dojrzałości. W tab. 4-8 zaprezentowano istotne statystycznie wartości współczynników korelacji między zmiennymi. 
Tabela 4. Związki pomiędzy czynnikiem 1 prężności a strategiami radzenia sobie ze stresem

\begin{tabular}{|c|c|}
\hline \multicolumn{2}{|c|}{ PRĘŻNOŚĆ 1 - Wytrwałość i determinacja w działaniu } \\
\hline ETAP I & ETAP ॥ \\
\hline $\begin{array}{l}\text { COPE } 1 \text { - Aktywne radzenie sobie } \\
\mathrm{r}=.21^{*}\end{array}$ & $\begin{array}{l}\text { COPE } 1-\text { Aktywne radzenie sobie } \\
\mathrm{r}=.30^{\star \star}\end{array}$ \\
\hline $\begin{array}{l}\text { COPE } 13-\text { Zaprzestanie działań } \\
\mathrm{r}=-.35^{* *}\end{array}$ & $\begin{array}{l}\text { COPE } 13 \text { - Zaprzestanie działań } \\
\mathrm{r}=-.42^{* * *}\end{array}$ \\
\hline $\begin{array}{l}\text { COPE } 5 \text { - Unikanie konkurencyjnych działań } \\
\mathrm{r}=.27^{* *}\end{array}$ & $\begin{array}{l}\text { COPE } 11 \text { - Zaprzeczanie } \\
r=-.32^{* *}\end{array}$ \\
\hline $\begin{array}{l}\text { COPE } 6-\text { Zwrot ku religii } \\
r=.23^{*}\end{array}$ & $\begin{array}{l}\text { COPE } 12-\text { Odwracanie uwagi } \\
r=-.38^{* *}\end{array}$ \\
\hline $\begin{array}{l}\text { COPE } 15-\text { Poczucie humoru } \\
r=-.20^{*}\end{array}$ & $\begin{array}{l}\text { COPE } 14 \text { - Zażywanie alkoholu lub innych środków } \\
\text { psychoaktywnych } \\
r=-.38^{\star *}\end{array}$ \\
\hline
\end{tabular}

${ }^{*} p<.05 ;{ }^{* *} p<.01 ;{ }^{* * *} p<.001$

Im wyższą wytrwałość i determinację w działaniu przejawiała badana młodzież na 3 miesiące przed maturą (etap 1), tym częściej korzystała z aktywnego radzenia sobie, unikania konkurencyjnych działań i zwrotu ku religii, a rzadziej z zaprzestania działań i poczucia humoru. Z kolei przed samym egzaminem (etap 2) występują podobne i nieco silniejsze zależności aktywnego radzenia sobie i zaprzestania działań z czynnikiem 1 prężności, natomiast dodatkowo skorelowane z nim (ujemnie) było zażywanie alkoholu lub innych środków, odwracanie uwagi i zaprzeczanie.

Tabela 5. Związki pomiędzy czynnikiem 2 prężności a strategiami radzenia sobie ze stresem

\begin{tabular}{|l|l|}
\hline \multicolumn{2}{|c|}{ PRĘŻNOŚĆ 2 - Otwartość na nowe doświadczenia i poczucie humoru } \\
\hline \multicolumn{1}{|c|}{ ETAP I } & \multicolumn{1}{|c|}{ ETAP II } \\
\hline $\begin{array}{l}\text { COPE 1 - Aktywne radzenie sobie } \\
r=.29^{* *}\end{array}$ & $\begin{array}{l}\text { COPE 1 - Aktywne radzenie sobie } \\
r=.28^{*}\end{array}$ \\
\hline $\begin{array}{l}\text { COPE 7 - Pozytywne przewartościowanie i rozwój } \\
r=.49^{* * *}\end{array}$ & $\begin{array}{l}\text { COPE 7 - Pozytywne przewartościowanie i rozwój } \\
r=.40^{* * *}\end{array}$ \\
\hline $\begin{array}{l}\text { COPE 3 - Poszukiwanie wsparcia instrumentalnego } \\
r=.21^{*}\end{array}$ & $\begin{array}{l}\text { COPE 14 -Zażywanie alkoholu lub innych środków } \\
\text { ssychoaktywnych } \\
r=.29^{*}\end{array}$ \\
\hline $\begin{array}{l}\text { COPE 15 - Poczucie humoru } \\
r=.37^{* * *}\end{array}$ & \\
\hline
\end{tabular}

${ }^{*} \mathrm{p}<.05 ;{ }^{* *} \mathrm{p}<.01 ;{ }^{* * *} \mathrm{p}<.001$ 
Nina Ogińska-Bulik, Magdalena Zadworna-Cieślak Rola prężności psychicznej w radzeniu...

Strategiami dodatnio powiązanymi z otwartością na nowe doświadczenia i poczuciem humoru w czasie poprzedzającym maturę o 3 miesiące było w świetle badań aktywne radzenie sobie, poszukiwanie instrumentalnego wsparcia, pozytywne przewartościowanie (najsilniejsza korelacja) oraz poczucie humoru. $\mathrm{Na} 2$ tygodnie przed maturą takie związki wystapiły już tylko w zakresie aktywnego radzenia sobie, pozytywnego przewartościowania i zażywania środków psychoaktywnych.

Tabela 6. Związki pomiędzy czynnikiem 3 prężności a strategiami radzenia sobie ze stresem

\begin{tabular}{|l|l|}
\hline \multicolumn{2}{|c|}{ PRĘŻNOŚĆ 3 - Kompetencje osobiste i tolerancja negatywnych emocji } \\
\hline \multicolumn{1}{|c|}{ ETAP I } & \multicolumn{1}{c|}{ ETAP II } \\
\hline $\begin{array}{l}\text { COPE 7 - Pozytywne przewartościowanie i rozwój } \\
r=.25^{*}\end{array}$ & $\begin{array}{l}\text { COPE 7 - Pozytywne przewartościowanie i rozwój } \\
\mathrm{r}=.37^{* *}\end{array}$ \\
\hline $\begin{array}{l}\text { COPE 13 - Zaprzestanie działań } \\
\mathrm{r}=-.36^{* *}\end{array}$ & $\begin{array}{l}\text { COPE 13 - Zaprzestanie działań } \\
\mathrm{r}=-.52^{* * *}\end{array}$ \\
\hline $\begin{array}{l}\text { COPE 1 - Aktywne radzenie sobie } \\
\mathrm{r}=.23^{*}\end{array}$ & $\begin{array}{l}\text { COPE 11-Zaprzeczanie } \\
\mathrm{r}=-.41^{* * *}\end{array}$ \\
\hline $\begin{array}{l}\text { COPE 10 - Koncentracja na emocjach i ich wyłado- } \\
\text { wanie } \\
r=-.40^{* * *}\end{array}$ & \\
\hline${ }^{*} \mathrm{p}<.05 ;{ }^{* *} \mathrm{p}<.01 ;{ }^{* * *} \mathrm{p}<.001$ & \\
\hline
\end{tabular}

Z poczuciem kompetencji osobistych i tolerancją negatywnych emocji było dodatnio powiązane pozytywne przewartościowanie i rozwój oraz ujemnie - zaprzestanie działań - na 3 miesiące przed egzaminem, a w jeszcze wyższym stopniu - tuż przed egzaminem. Pozostałe czynniki powiązane z kompetencjami osobistymi to koncentracja na emocjach i ich wyładowanie oraz aktywne radzenie sobie (w pierwszym etapie), a także zaprzeczanie (w drugim etapie).

Tabela 7. Związki pomiędzy czynnikiem 4 prężności a strategiami radzenia sobie ze stresem

\begin{tabular}{|l|l|}
\hline \multicolumn{2}{|c|}{ PRĘŻNOŚĆ 4 - Tolerancja na niepowodzenia i traktowanie życia jako wyzwania } \\
\hline \multicolumn{1}{|c|}{ ETAP I } & \multicolumn{1}{|c|}{ ETAP II } \\
\hline $\begin{array}{l}\text { COPE 3 - Poszukiwanie wsparcia instrumentalnego } \\
\mathrm{r}=.36^{* *}\end{array}$ & $\begin{array}{l}\text { COPE 3 - Poszukiwanie wsparcia instrumentalnego } \\
\mathrm{r}=.37^{* *}\end{array}$ \\
\hline $\begin{array}{l}\text { COPE 4 - Poszukiwanie wsparcia emocjonalnego } \\
\mathrm{r}=.31^{* *}\end{array}$ & $\begin{array}{l}\text { COPE 4 - Poszukiwanie wsparcia emocjonalnego } \\
\mathrm{r}=.32^{* *}\end{array}$ \\
\hline
\end{tabular}


Tabela 7. Cd.

\begin{tabular}{|l|l|}
\hline $\begin{array}{l}\text { COPE } 7-\text { Pozytywne przewartościowanie i rozwój } \\
r=.41^{* * *}\end{array}$ & $\begin{array}{l}\text { COPE } 7-\text { Pozytywne przewartościowanie i rozwój } \\
r=.34^{* *}\end{array}$ \\
\hline $\begin{array}{l}\text { COPE } 11-\text { Zaprzeczanie } \\
r=-.24^{*}\end{array}$ & $\begin{array}{l}\text { COPE } 11-\text { Zaprzeczanie } \\
\mathrm{r}=-.44^{\star * *}\end{array}$ \\
\hline $\begin{array}{l}\text { COPE } 13-\text { Zaprzestanie działań } \\
r=-.34^{* *}\end{array}$ & $\begin{array}{l}\text { COPE } 13-\text { Zaprzestanie działań } \\
r=-47^{* \star *}\end{array}$ \\
\hline $\begin{array}{l}\text { COPE } 1-\text { Aktywne radzenie sobie } \\
r=.38^{* *}\end{array}$ & \\
\hline $\begin{array}{l}\text { COPE } 2-\text { Planowanie } \\
r=.21^{*}\end{array}$ & \\
\hline $\begin{array}{l}\text { COPE } 5-\text { Unikanie konkurencyjnych działań } \\
r=.24^{*}\end{array}$ & \\
\hline
\end{tabular}

${ }^{*} p<.05 ;{ }^{* *} p<.01 ;{ }^{* * *} p<.001$

Czynnik 4 prężności, jakim jest tolerancja na niepowodzenia i traktowanie życia jako wyzwania, był skorelowany z największą liczbą strategii radzenia sobie, zwłaszcza w etapie 1, czyli na 3 miesiące przed maturą. Najsilniejsze związki dotyczyły pozytywnego przewartościowania i aktywnego radzenia sobie w etapie 1 oraz zaprzestania działań i zaprzeczania w etapie 2. Dodatnio powiązane z czynnikiem 4 prężności okazało się też poszukiwanie wsparcia społecznego, zarówno instrumentalnego, jak emocjonalnego, i to w obydwu etapach badania.

Optymistyczne nastawienie do życia i zdolność mobilizowania się w trudnych sytuacjach były powiązane - zarówno na 3 miesiące, jak i 2 tygodnie przed matura - z aktywnym radzeniem sobie, pozytywnym przewartościowaniem (dodatnio) i zaprzestaniem działań (ujemnie). Wyraźnie silniejsze zależności odnoszą się do etapu 2 .

Tabela 8. Związki pomiędzy czynnikiem 5 prężności a strategiami radzenia sobie ze stresem

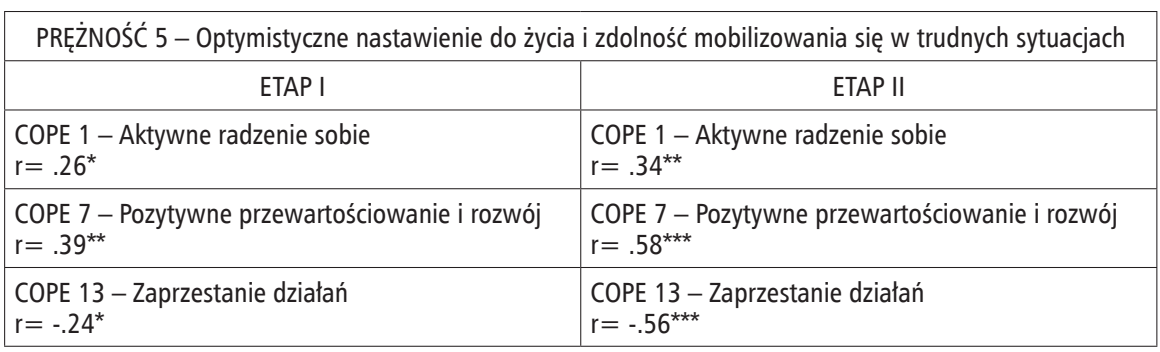


Tabela 8. Cd.

\begin{tabular}{|l|l|}
\hline $\begin{array}{l}\text { COPE } 10-\text { Koncentracja na emocjach i ich wyłado- } \\
\text { wanie } \\
r=-.28^{* *}\end{array}$ & $\begin{array}{l}\text { COPE 2 }- \text { Planowanie } \\
\mathrm{r}=.37^{\star *}\end{array}$ \\
\hline & $\begin{array}{l}\text { COPE } 11-\text { Zaprzeczanie } \\
\mathrm{r}=-.36^{* *}\end{array}$ \\
\hline
\end{tabular}

${ }^{*} \mathrm{p}<.05 ;{ }^{* *} \mathrm{p}<.01 ;{ }^{* * *} \mathrm{p}<.001$

Ponadto istotne współczynniki korelacji uzyskano także w przypadku koncentracji na emocjach (1 etap) oraz planowania i zaprzeczania (2 etap). Ogólnie, im bardziej optymistyczna postawa i przekonanie o zdolnościach mobilizowania się w trudnych chwilach, tym większa skłonność do wykorzystywania w sytuacji zbliżającego się stresu egzaminacyjnego przystosowawczych strategii radzenia sobie, przede wszystkim aktywnego radzenia sobie, planowania i pozytywnego przewartościowania, a mniejsza do strategii unikowych, takich jak zaprzestanie działań i zaprzeczanie.

\section{Podsumowanie i dyskusja wyników}

Przeprowadzone badania wykazały duże zróżnicowanie wykorzystywanych przez młodzież strategii radzenia sobie ze stresem maturalnym. Znajduje to potwierdzenie $w$ innych badaniach (Compass i in., 2001; Pisula, 2003; Zeidner, 1995).

Badana młodzież wykorzystuje w procesie radzenia sobie ze stresem egzaminacyjnym strategie, pełniące zarówno funkcję instrumentalną - służą poradzeniu sobie z problemem, jak i emocjonalną - których celem jest regulacja emocji, a przede wszystkim zmniejszenie napięcia i obniżenie poziomu lęku, niezależnie od zbliżającego się terminu egzaminu. Najrzadziej stosowane były strategie unikowo-ucieczkowe, takie jak zażywanie alkoholu i innych substancji psychoaktywnych, zaprzestanie działań czy zaprzeczanie. Na podobne rezultaty wskazują Janis Gibson i in. (1991) oraz Tim Gelhaar i in. (2007), podkreślając, że w fazie przygotowania do egzaminu najczęściej wykorzystywane przez nastolatków są strategie skoncentrowane na problemie, zmniejsza się natomiast tendencja do wykorzystywania strategii unikowych.

Preferencje badanych nastolatków w zakresie strategii radzenia sobie nie zmieniły się w zasadniczy sposób w zależności od terminu zbliżania się do egzaminu maturalnego. Zmiany te zaobserwowano jedynie w odniesieniu do 3 spośród 15 strategii wchodzących w skład inwentarza COPE. Wraz z upływem czasu, jaki pozostał do egzaminu maturalnego, u badanej młodzieży zwiększyła 
się skłonność do korzystania ze strategii planowania, zmniejszeniu zaś uległa preferencja do poszukiwania emocjonalnego wsparcia i akceptacji. Świadczy to o stabilności preferowanych sposobów radzenia sobie. Może także sugerować, że sytuacyjne radzenie sobie nie różni się w zasadniczy od dyspozycyjnego choć $\mathrm{w}$ tym przypadku nie analizowano tego drugiego. Byłoby to zgodne z założeniami Carvera i Scheiera (1994), którzy zakładali znaczne podobieństwo sposobów radzenia sobie w sytuacjach ogólnych i specyficznych.

Ponadto przeprowadzone badania wskazują na istotną rolę prężności w doborze strategii radzenia sobie ze stresem egzaminacyjnym, choć uzyskane zależności można uznać co najwyżej za umiarkowane. Właściwość osobowości, jaką jest prężność psychiczna, okazała się powiązana ze strategiami radzenia sobie, które pełnią zarówno funkcję instrumentalną, jak i emocjonalną. Co ciekawe, w obydwu etapach badań prężność (traktowana jako wynik ogólny SPP-25) silniej wiązała się ze strategią, jaką jest pozytywne przewartościowanie i rozwój (etap 1 i 2) oraz zaprzestaniem działań (etap 2) niż strategią aktywnego radzenia sobie. Podobne tendencje pojawily się w odniesieniu do poszczególnych wymiarów, składających się na prężność psychiczną. Najwięcej związków ze strategiami radzenia sobie wykazuje czynnik 4 , tj. tolerancja na niepowodzenia i traktowanie życia jako wyzwania. Zanotowano tu istotne zależności nie tylko w odniesieniu do strategii, które wiązały się z innymi czynnikami prężności, ale także z poszukiwaniem wsparcia społecznego, zarówno instrumentalnego, jak i emocjonalnego, i to w obydwu etapach badania (zależność dodatnia).

Rola prężności w doborze strategii radzenia sobie ze stresem maturalnym okazała się zgodna z przewidywaniami. Prężność, a szczególnie jej dwa czynniki, tj. kompetencje osobiste i tolerancja negatywnych emocji (cz. 3) oraz optymistyczne nastawienie do życia i zdolność mobilizowania się w trudnych sytuacjach (cz. 5) sprzyjają podejmowaniu przystosowawczych strategii i zmniejszają skłonność do korzystania ze strategii nieadaptacyjnych. Znaczenie prężności $\mathrm{w}$ procesie radzenia sobie zwiększa się wraz ze zbliżaniem się terminu egzaminu, co potwierdza jej rolę jako czynnika sprzyjającego skutecznemu radzeniu sobie czy odnoszeniu sukcesu w sytuacjach stresujących. Jednak niespodziewanym wynikiem okazała się pozytywna, choć słaba, zależność otwartości na nowe doświadczenia i poczucia humoru (cz. 2) ze skłonnością do zażywania alkoholu lub innych środków psychoaktywnych. Wskazuje to, że osoby, które przejawiają wysoki poziom otwartości na nowe doświadczenia - co może być powiązane ze skłonnością do poszukiwania nowych doznań - w sytuacji zwiększonego poziomu stresu (etap 2), wykazują preferencje do ucieczki w alkohol. Uzyskany wynik może sugerować niejednoznaczną rolę 
prężności w doborze strategii radzenia sobie. Jej składnik, jakim jest otwartość na nowe doświadczenia, może sprzyjać w sytuacji silnego stresu podejmowaniu nieadaptacyjnych strategii radzenia sobie. Być może można tu mówić o dwóch stronach prężności - pozytywnej i negatywnej. Byłoby to zgodne z zaproponowanym przez George'a Bonanno i Maren Westphal (2007) oraz przytaczanym przez Pawła Izdebskiego i Małgorzatę Suprynowicz (2011) rozróżnieniem na pozytywny i negatywny wymiar prężności. Ten negatywny obejmuje nieadaptacyjne radzenie sobie, określane także jako tzw. brzydkie radzenie sobie (copingugly), odnoszące się do używania strategii służących rozładowaniu napięcia związanego z doświadczaną sytuacją. Zagadnienie to wymagałoby jednak dalszych badań.

Siłę związku między prężnością a sposobami radzenia sobie ze stresem egzaminacyjnym można określić jako umiarkowaną. Udział w procesie radzenia sobie ze stresem przypisuje się także innym właściwościom podmiotowym, wśród których wymienia się m.in.: stabilność emocjonalną, poczucie koherencji, własnej wartości, skuteczności czy optymizm życiowy (Heszen-Niejodek, 2002, Juczyński, 2010; Ogińska-Bulik, 2012, Ogińska-Bulik, Juczyński, 2010). Prężność psychiczna prawdopodobnie ma większe znaczenie dla radzenia sobie ze stresem o charakterze ekstremalnym, związanym z doświadczaniem zdarzeń traumatycznych. Przypuszczalnie odgrywa ona rolę bufora, czyli czynnika chroniącego przed negatywnymi skutkami doświadczanych zdarzeń. Świadczą o tym wyniki badań Sandry Prince-Embury (2007) wskazujące, że młodzież $\mathrm{z}$ wysokim nasileniem prężności w porównaniu z jednostkami o niskim nasileniu tej zmiennej, wykazywała lepszą adaptację do takich wydarzeń życiowych jak rozwód rodziców czy bycie ofiarą przemocy domowej. Z kolei z badań Phyllis Silverman i James'aWorden'a (za: Clark i in., 1999) wynika, że 83\% dzieci charakteryzujących się wysokim nasileniem prężności skutecznie poradziło sobie ze śmiercią któregoś z rodziców w okresie 4 miesięcy od wystąpienia zdarzenia.

Na zakończenie należy zwrócić uwagę na ograniczenia przeprowadzonych badań. Obejmowały one stosunkowo niewielką liczbę uczniów przygotowujących się do egzaminu maturalnego. Ponadto nie badano poczucia stresu; założono, że on występuje, a skoncentrowano się jedynie na ocenie wykorzystywanych strategii radzenia sobie. Nie kontrolowano także wpływu niektórych czynników socjodemograficznych, mogących mieć znaczenie w procesie radzenia sobie, np. związanych z sytuacją rodzinną. Ponadto trudno jednoznacznie określić, czy czas, w jakim przeprowadzono badanie, zwłaszcza etap 1 (3 miesiące przed egzaminem), można uznać za właściwą fazę przygotowaw- 
czą egzaminu maturalnego. Ponadto czas pomiędzy dokonanymi pomiarami preferowanych strategii radzenia sobie (3 miesiące) może wydawać się zbyt krótki. Być może nie pozwoliło to na uchwycenie dynamiki zmian w zakresie ich stosowania. W przyszłości, prowadząc badania nad stresem egzaminacyjnym, warto byłoby uwzględnić ocenę nasilenia stresu oraz ocenę zarówno sytuacyjnego, jak i dyspozycyjnego radzenia sobie.

\section{Bibliografia}

Block J. H., Block J. (1980), The role of ego-control and ego-resiliency in the origination of behaviour,[w:] W. A. Collings (red.), The Minnesota Symposia on Child Psychology,Hillsdale, Erlbaum, New York.

Block J., Kremen, A. M. (1996), IQ and ego-resiliency: Conceptual and empirical connections and separateness. "Journal of Personality and Social Psychology", nr 70, s. 349-361, DOI: http://dx.doi.org/10.1037/0022-3514.70.2.349

Bonanno, G. A., Westphal M. (2007), Posttraumatic growth and resilience to trauma: different sides of the same coin of different coins?, "Applied Psychology", nr 56, s. 417-427.

Carver C., Scheier M. (1994), Situational coping and coping dispositions in a stressful transaction, "Journal of Personality and Social Psychology", nr 66 (1), s. 184-195, DOI: http://dx.doi.org/10.1037//0022-3514.66.1.184

Chanduszko-Salska J., Ogińska-Bulik N. (2011), Prężność a ryzyko uzależnienia od jedzenia,[w:] L. Golińska, E. Bielawska-Batorowicz (red), Rodzina i praca w warunkach kryzysu, Wydawnictwo UŁ, Łódź.

Clark D., Pynoos R., Goebel A. (1999), Mechanisms and processes of adolescent bereavement, [w:] R. Haggerty, L. Sherrod, N. Garmezy, M. Rutter (red.), Stress, risk and resilience in children and adolescents, Cambridge University Press, Cambridge.

Compas, B., Connor-Smith, J., Saltzman, H., Harding Thomsen, A., Wadsworth, M. (2001), Coping with stress during childhood and adolescence: problems, progress, and potential in theory and research, "Psychological Bulletin", nr 127, s. 87-127, DOI:http:// dx.doi.org/10.1037//0033-2909.127.1.87

Chuang, S., Lamb, M., Hwang, C. (2006), Personality development from childhood to adolescence: A longitudinal study of ego-control and ego-resiliency in Sweden, "International Journal of Behavioral Development", nr 30 (4), s. 338-343, DOI: http://dx.doi. org/10.1177/0165025406072795

Felcyn-Koczewska M., Ogińska-Bulik N. (2011), Rola prężności w rozwoju potraumatycznym osób w żatobie, [w:] L. Golińska, E. Bielawska-Batorowicz (red.), Rodzina i praca w warunkach kryzysu, Wydawnictwo UŁ, Łódź. 
Nina Ogińska-Bulik, Magdalena Zadworna-Cieślak Rola prężności psychicznej w radzeniu...

Fredrickson B. (2001), The role of positive emotions in positive psychology: The broaden-and build theory of positive emotions, "AmericanPsychologist", $\mathrm{nr} 56$, s. 218-226, DOI: http://dx.doi.org/10.1037//0003-066X.56.3.218

Gelhaar T., Seiffge-Krenke I., Borge A., Cicognani E., Cunha M., Loncaric D. (2007), Adolescent coping with everyday stressors: A seven-nation study of youth from central, eastern, southern and northern Europe, "European Journal of Developmental Psychology”, nr 4 (2), s. 129-156, DOI: http://dx.doi.org/10.1080/17405620600831564

Gibson J. T., Westwood M. J., Ishiyama F. I., Borgen W. A., Showalter S. M., Al-Saraff Q. (1991), Youth and culture: A seventeen nation study of perceived problems and coping strategies, "International Journal for the Advancement of Counselling", nr 14, s. 203-216, DOI: http://dx.doi.org/10.1007/BF00119183

Heszen-Niejodek I. (2002), Emocje, ocena poznawcza i strategie w procesie radzenia sobie, [w:] I. Heszen-Niejodek (red), Teoretyczne i kliniczne aspekty radzenia sobie ze stresem psychologicznym, Wydawnictwo Stowarzyszenie Psychologia i Architektura, Poznań.

Izdebski P., Suprynowicz M. (2011), Rozwój pourazowy a prężność. Nauki o Edukacji, „Rocznik Naukowy Kujawsko-Pomorskiej Szkoły Wyższej w Bydgoszczy”, nr 5, s. $61-69$.

Juczyński Z., Ogińska-Bulik N. (2009), Narzędzia pomiaru stresu i radzenia sobie ze stresem, Pracownia Testów Psychologicznych, Warszawa.

Klohnen E. C. (1996), Conceptual analysis and measurement of the construct of ego-resiliency, "Journal of Personality and Social Psychology", nr 70, s. 1067-1079, DOI: http:// dx.doi.org/10.1037//0022-3514.70.5.1067

Luthar S., Cicchetti D., Becker B. (2000), The construct of resilience: critical evaluation and guidelines for future work, "Child Development”, nr 71, s. 543-562, DOI: http://dx.doi. org/10.1111/1467-8624.00164

Ogińska-Bulik N. (2010), Szkoła jako środowisko kształtowania psychologicznych zasobów jednostki chroniacych przed podejmowaniem zachowań ryzykownych - rola prężności, [w:] D. Bilski (red.), Szkoła jako środowisko edukacji zdrowotnej, Wydawnictwo WSEZiNS, Łódź.

Ogińska-Bulik N. (2011a), Rola prężności w zapobieganiu negatywnym skutkom stresu zawodowego, [w:] L. Golińska, E. Bielawska-Batorowicz (red.), Rodzina i praca w warunkach kryzysu, Wydawnictwo UŁ, Łódź.

Ogińska-Bulik N. (2011b), Rola prężności psychicznej w przystosowaniu się kobiet do choroby nowotworowej, „Psychoonkologia”, nr 1, s. 26-35.

Ogińska-Bulik N. (2012), Stres i radzenie sobie, [w:] E. Bielawska-Batorowicz (red.), Wprowadzenie do psychologii dla ekonomistów, PWE, Warszawa. 
Ogińska-Bulik N., Juczyński Z. (2008), Skala pomiaru prężności-SPP-25, „Nowiny Psychologiczne", nr 3, s. 39-56.

Ogińska-Bulik, N., Juczyński, Z. (2010 - wyd. II uzup.), Osobowość, stres a zdrowie, Wydawnictwo Difin, Warszawa.

Ogińska-Bulik N., Juczyński Z. (2011), Prężność u dzieci i młodzieży: charakterystyka i pomiar - polska skala SPP-18, „Polskie Forum Psychologiczne”, nr 16 (1), s. 7-28.

Oleś P. (2000), Psychologia przełomu połowy życia, Wydawnictwo KUL, Lublin.

Oshio, A., Kaneko, H., Nagamine, S., Nakaya, M. (2003), Construct validity of the Adolescent Resilience Scale, "Psychological Reports", nr 93, s. 1217-1222, DOI: http:// dx.doi.org/10.2466/PR0.93.8.1217-1222

Oshio A., Nakaya M., Kaneko H., Nagamine S. (2002), Development and validation of an Adolescent Resilience Scale, "Japanese Journal of Counseling Science”, nr 35, s. 57-65.

Pisula E. (2003), Środowiskowe i osobowościowe uwarunkowania radzenia sobie ze stresem przez dzieci i młodzież, [w:] A. Jurkowski (red.), Z zagadnień wspótczesnej psychologii wychowawczej, Wydawnictwo IP PAN, Warszawa.

Prince-Embury S. (2007), Resiliency scales for children and adolescents: A profile of personal strengths, "Canadian Journal of School Psychology", nr 22 (2), s. 255-261.

Robins R. W., John O. P., Caspi A., Moffitt T. E., Stouthamer-Loeber M. (1996), Resilient, overcontrolled, and undercontrolled boys. Three replicable personality types, "Journal of Personality and Social Psychology", nr 70, s. 157-171, DOI: http://dx.doi. org/10.1037//0022-3514.70.1.157

Torgersen S., Vollrath M. (2006), Personality types, personality traits, and risky health behavior, [w:] M. Vollrath (red.), Handbook of Personality and Health, Wiley, Chichester.

Semmer N. (2006),Personality, stress and coping,[w:] M. Vollrath (red.), Handbook of Personality and Health, Wiley, Chichester.

Uchnast Z. (1997), Prężność osobowa: Empiryczna typologia i metoda pomiar, „Roczniki Filozoficzne", nr XLV (4), s. 27-49.

Zeidner M., (1995), Adaptive coping with test situations. A review of literature, "Educational Psychologist", nr 30 (3), s. 123-133, DOI: http://dx.doi.org/10.1207/ s15326985ep3003_3 